\title{
腐蝕性喉頭咽頭食道炎の一再建例
}

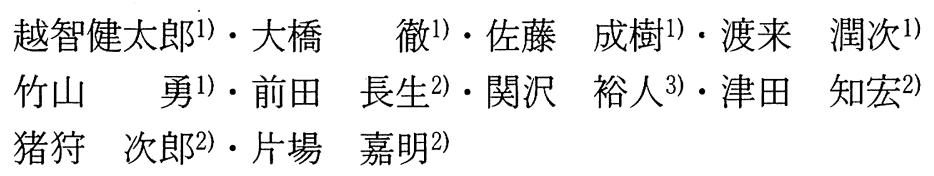

\section{Reconstructive Surgery for Extensive Stenosing Caustic Burns of the Hypopharynx, Larynx and Esophagus}

\author{
Kentaro Ochi, Toru Ohashi, Shigeki Sato, Junji Watarai, \\ Isamu Takeyama, Chosei Maeda, Yuto Sekizawa, \\ Tomohiro Tsuda, Jiro Ikari and Yoshiaki Kataba
}

(St. Marianna University School of Medicine)

\begin{abstract}
Caustic ingestion may cause severe necrosis of upper digestive tract. Combined pharyngeal and esophageal stricture is unusual, but when it occurs, reconstructive surgery neccessitates difficult techniques. There are special problems in these cases involving on the function of both deglutition and phonation.

A 45-year-old female with severe pharyngoesophageal involvement was treated by colon interposition with particular emphasis placed on the cervical anastomosis. From the point of natural process of deglutition, it is thought that the posterior pharyngeal wall may be a better position for anastomosis than the vallecula. However, in this case, we placed the vallecula for anastomosis and met with good results.

The scarring tissue between epiglottis and posterior pharyngeal wall may serve to inhibit the aspiration in the this case.
\end{abstract}

Key words: caustic ingestion, vallecula, colon interposition, esophagitis

緒 言
酸，アルカリなどの腐蝕剂の誤飲による腐蝕 性変化は口腔, 咽頭さらに喉頭, 食道, 胃に及 び, その病態は腐蝕性薬剤の種類, 濃度, 量, 停滞時間などの因子に修飾される。また，その 治療は全身管理を要するもの，手術治療を要す るものなど多岐にわたる.手術治療のなかでも， 腐蝕性変化が下咽頭, 喉頭および食道に広範囲
にいたる症例は，その再建手術に困難を要し， 曣下および発声機能を温存することが重要とな る.

腐蝕剤の種類として, 本邦では酸性腐蝕剤に よる報告が多いが，欧米ではアルカリ性腐蝕剂 による報告が大半を占める1)2)。また，子供の 場合は，䛊飲によることが多く軽症例が多いが， 大人の場合は誤飲の他に意図的に飲用すること

1）聖マリアンナ医科大学耳鼻咽喉科学教室

2) 聖マリアンナ医科大学第 1 外科学教室

3）聖マリアンナ医科大学第 2 外科学教室 


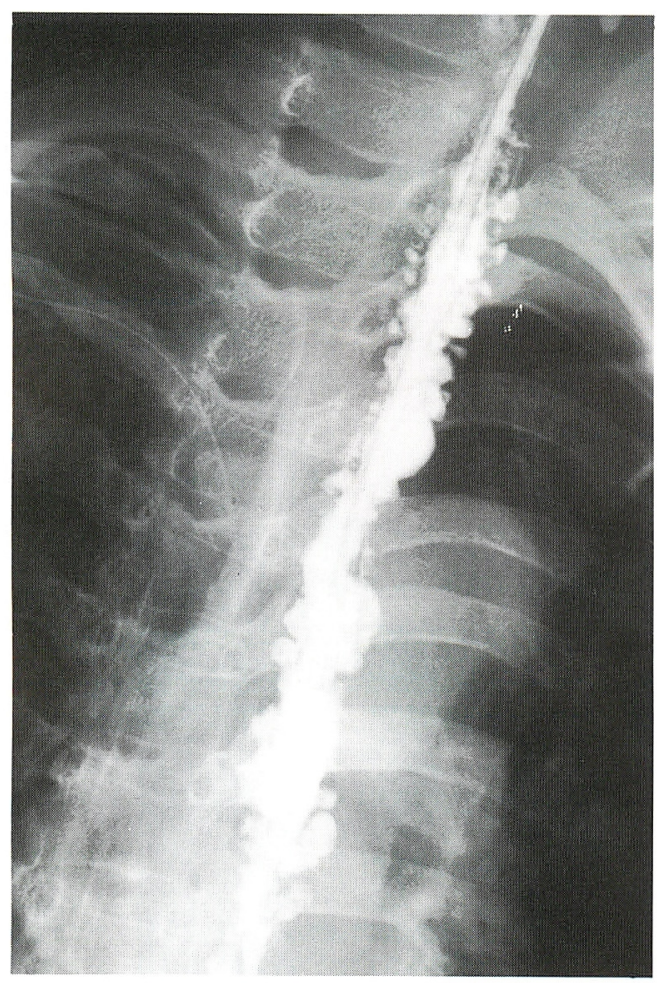

図 1 食道造影所見
があり重症例の報告が多(314).

今回，私どもは酸性トイレ洗浄剂を自殺目的 にて飲用し，下咽頭，喉頭および食道に強度の 腐蝕性変化をきたした症例を経験した。この症 例に対し結腸を用い，左側咽頭蓋谷を吻合部位 とした再建手術を施行したところ誤與などの術 後副作用もなく発声機能を温存し, 良好な経過 を兄られたが，本例の管理と治療法には問題点 も多いので，若干の文献的考察を加えて報告す る。

\section{症例}

患 者：45歳，女性

主 訴: 腐蝕剤飲用

既往歴 : 昭和 61 年 10 月夫を癌で失って以来反 応性うつ病との診断で当院精神科で外来経過観 察中.

家族歴：特記すべきことなし．

現病歴：昭和 63 年 4 月 2 日自殺目的にて酸性 トイレ洗浄剤を飲用し，さらに左側頸部をナイ フで切り聖マリアンナ医科大学横浜市西部病院 救命センターに搬送された。

切創は筋層にとどまって拈り一期的に縫合し

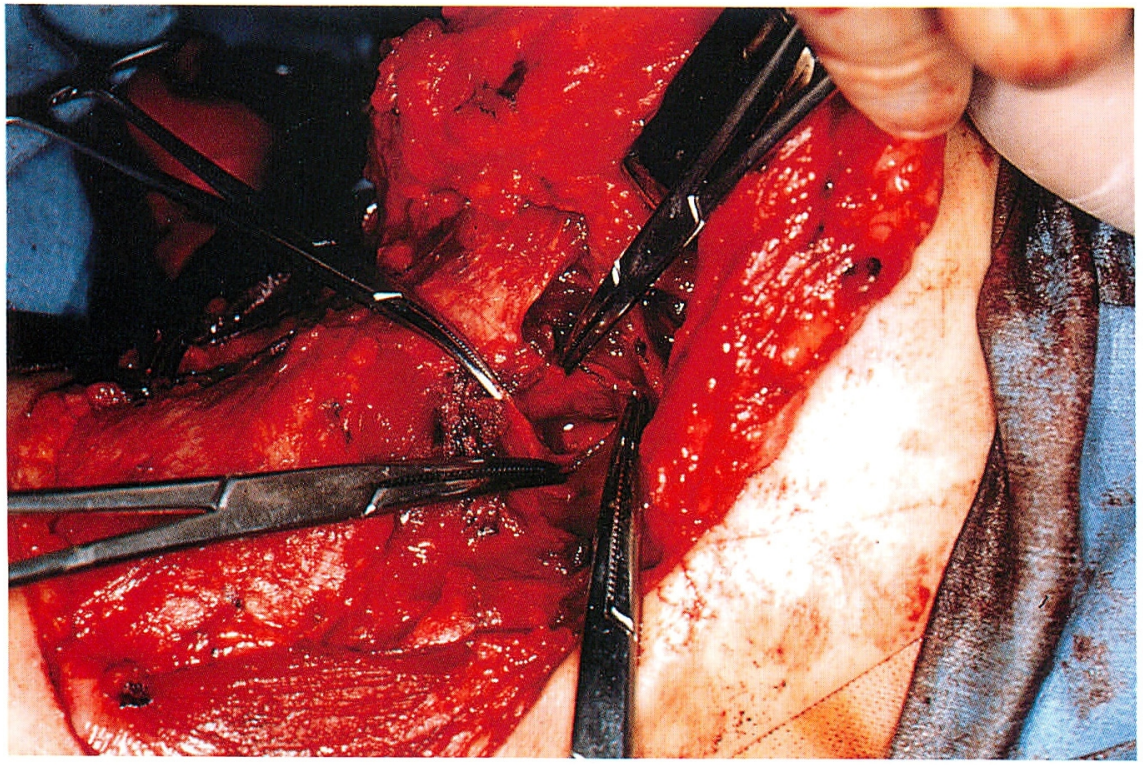

図 2 手術時所見 
た。食道内視鏡検査にて食道は全層にわたり浮 腫性変化があり潰瘍形成が認められたが，穿孔 等の所見はなかった。昭和63年 5 月26日の造影 検査では多数の憩室形成が認められた（図 1 ）.
ステロイド剤の点滴静注を施行したが，腐蝕性 変化が進行し内視鏡も挿入困難とあり，また， 喉頭蓋の咽頭後壁への瘉着も認められたため昭 和63年 9 月 2 日胃㾇造設術拉よび気管切開術を

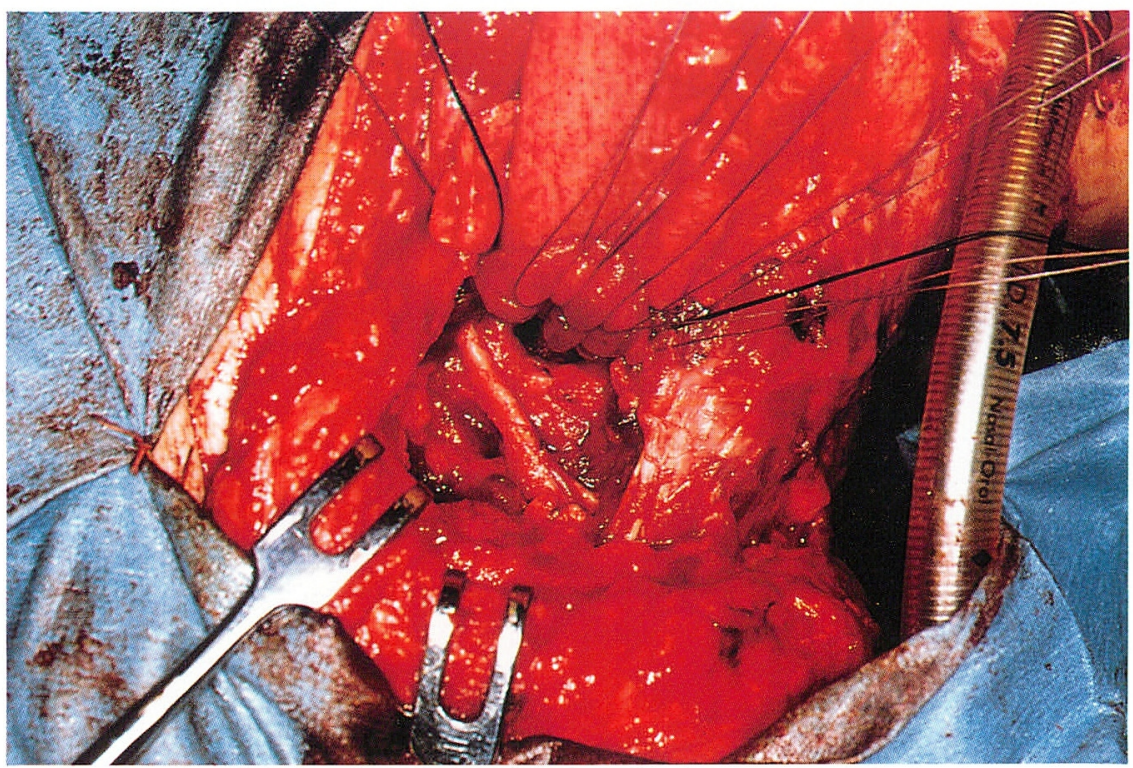

図 3 手術時所見

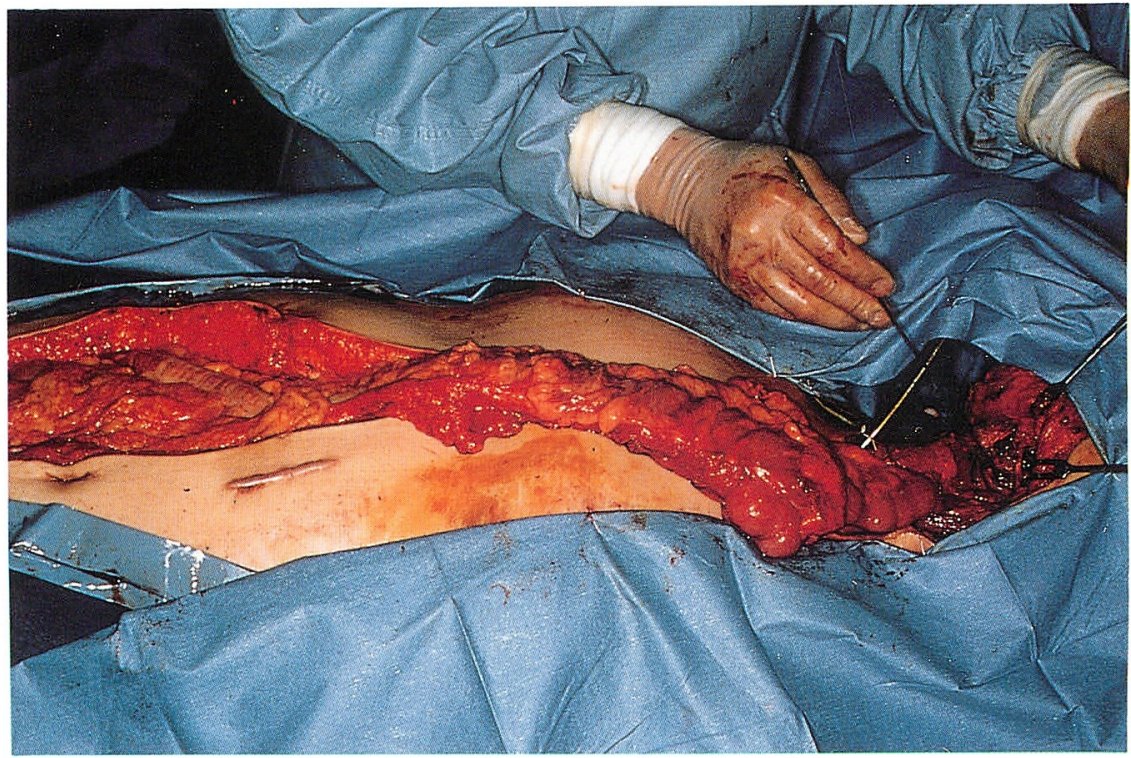

図 4 手術時所見 
施行した。

その後, 食道の瘢痕狭窄に対し食道ブジ一拡

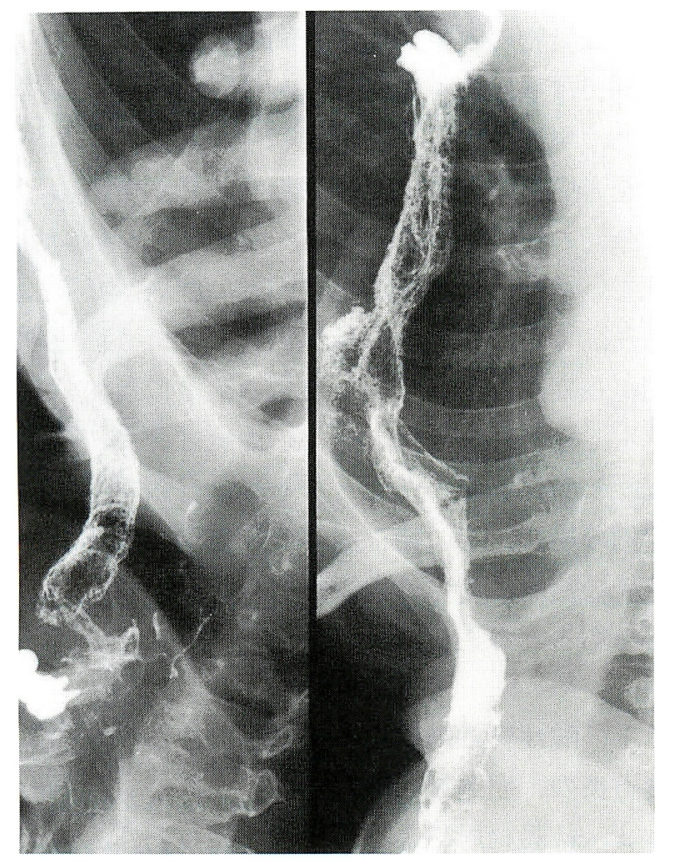

図 5 食道造影所見 左：正面像 右：側面像

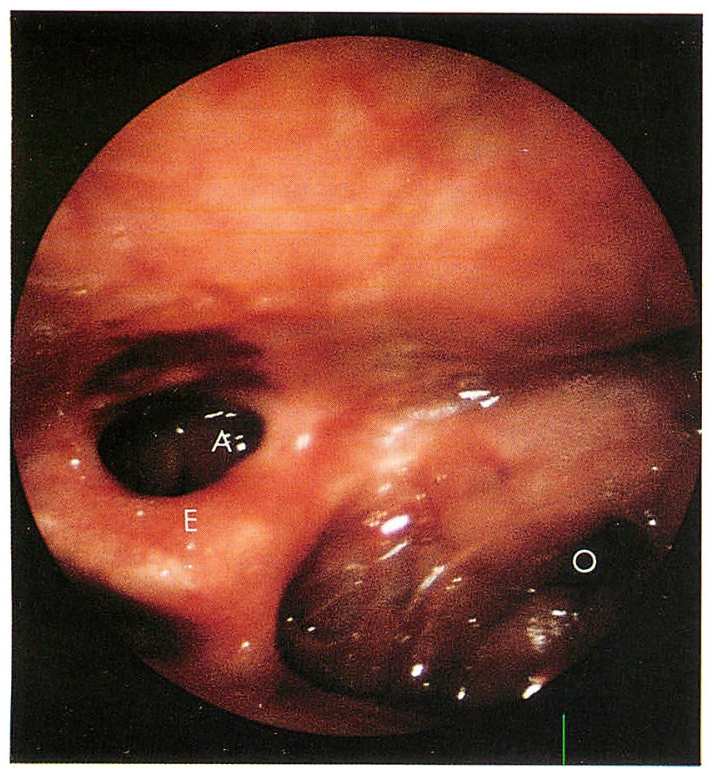

図 6 喉頭内視鏡所見
$\mathrm{A} ：$ 披裂部
$\mathrm{E}$ : 喉頭蓋
$\mathrm{O}:$ 造設した開口部

張術を施行したが改善せず平成元年 6 月 9 日下 咽頭食道再建手術を施行した. 手術は食道入口 部が疫痕組織により癒着し閉塞されていたため 新たに開口部を造設する必要があった。私ども は左側喉頭蓋谷を新しい開口部とし, 右半結腸 を用い回盲部を左側喉頭蓋谷に吻合し，肛側は 結腸・胃前庭部吻合術を行なった。図 2 は造設 した開口部を示したものである. 図 3 は造設し た開口部に結腸を縫合しているところである。

図 4 はその全様である。

術後與下の第 1 期がえられなかったが，與下 訓練を行ならことにより徐々に與下可能となっ た. 図 5 は術後の造影所見を示したものである。 誤嚥もなく造影剤が飲用され，狭窄等の所見も ない。術後の喉頭内視鏡所見を示したものが図 6 である. 喉頭蓋の咽頭後壁への癒着はあるが 発声機能は温存され, また, 再建結腸の開口部 が認められる. 平成 2 年 2 月 3 日退院し, 社会 復帰し現在に至っている. 今後喉頭蓋の咽頭後 壁からの切り離し, 気管切開孔の閉鎖扝よび食 道の切除術を行なら予定である。

\section{考察}

酸性腐蝕剤は組織蛋白と結合して酸・アルブ ミンとなり, 組織表面には早期に乾性凝固を生 じるため, 障害が組織深部に浸透せず変化は比 較的表層にとどまり限局することが多く，障害 部位は主として食道下部から胃, 十二指腸とさ れている。酸性剤では刺激臭が強いため大量の 飲用は困難であるとされている．

一方，アルカリ性腐蝕剤の場合はアルカリ・ アルブミンとなり湿性融解壊死を生じ，創面は 柔軟湿潤で障害は広範囲であり, 深層に及ぶこ とが多く, 障害部位は口腔内及び食道上部に多 いとされている。また, 刺激臭が弱いため大量 の飲用が可能であり酸性剂に比し侵される程度 や範囲が大きく，その腐蝕性変化が強いとされ ている。しかし, 障害の程度は, 濃度, 量, 表 面活性剤などの添加物の有無, 残留食物の有無, および飲用後の体位や接触時間などの因子によ り修飾される. 今回の症例の上うに酸性腐蝕剤 
にもかかわらず, 腐蝕性変化が下咽頭, 喉頭お よび食道に強く認められる例は比較的まれであ る。

腐蝕性食道炎の急性期以後の狭窄予防には早 期からのステロイド剤の大量投与と抗生剂の投 与が重要であるとされている5) 8). しかし，重 症の場合は狭窄も防げずかえって様々な症状が ステロイド剤のために把握しにくくなるので使 用すべきではないといら報告もある9).

従来, 早期の食道内視鏡は消化管穿孔を引き 起こす可能性があるため禁忌とされていたが細 径の内視鏡の開発に伴い, 上り安全性, 有用性 が向上し，さらに重傷損傷部位は数日後に穿孔 の可能性が高いといらこともあり，むしろ早期 に施行し受傷の程度を把握し治療方針を決定す ることが重要とされている113) 519)10)。急性期以 後の食道狭窄に対する治療としては以前よりブ ジー, Hacker の無端拡張法5) に上る食道拡張 術が施行され，その有効性が確認されている. また，狭窄部が短いものには内視鏡下切開拡張 術も施行されているが6)，近年瘢痕狭窄部より の発癌性を考慮し11), 保存的治療よりも食道切 除術拉よび再建術が推奖されつつある.

再建術は多々報告されているが，結腸利用に よるものが近年多くの施設で行なわれている. 今回, 私どもは結腸利用により発声, 與下両機 能を損ならことなく良好な経過をえることがで きた。腐蝕性変化が，喉頭，下咽頭および食道 入口部におよんでいない場合は再建術は比較的 容易であるが，喉頭，下咽頭および食道入口部 におよんでいる場合は発声機能と與下機能を損 なわないことが重要となり, その再建術には困 難と工夫を要す。一般的に新しく開口部を造設 する場合は正常食道に近い位置, 寸なわち咽頭 後壁に造設する報告12) が多いが，私どもの症 例は，喉頭蓋及び下咽頭の腐蝕性変化が強く左 側咽頭蓋谷に吻合した．位置的には正常解剖と 前後の位置関係が逆となるが，本症例の場合， 喉頭蓋が咽頭後壁と癒着していることもあり， 與下の第 2 期を行ならのに最適の位置と考えら
れた. 術後の造影叔よび内視鏡所見でも通過障 害はなく，逆流も認められなかった，従来の報 告のよらに咽頭後壁に新しく開口部を造設した 場合は食物の䛊嚥が大きな問題となるが，この 症例では喉頭蓋谷に開口部を造設し再建に成功 した. 現在外来にて経過観察中であるが，発癌 性を考慮して食道は今後切除する予定である.

今回の症例の場合，患者が反応性うつ病を患 っていたため, 精神的な要因への配虑が必要で あり，さらに腐蝕性変化が遷延したため治療期 間が長期にわたったが，患者の治療に対する意 欲もえられ社会復帰できた。治療は発声, 與下 機能の温存がその中心となるが，自殺に至った 症例の場合, その精神面への配慮が必要であり, 患者の治療に対する意欲を引き起こすことが重 要であると考えられた。

\section{まとめ}

1. 酸性腐蝕剂飲用による腐蝕性, 喉頭咽頭, 食道炎の 1 症例を経験した。

2 、結腸利用による再建術を施行した。

3. 口側の吻合を左側喉頭蓋谷に行なったが, この症例の場合嚥下第 2 期を行うのに最適の位 置と考兄られた。

4. 術後に誤與もなく発声機能を温存でき, 現在は社会復帰している.

5. 今後, 食道切除術, 喉頭蓋の下咽頭後壁 からの切り離し術および気管切開孔の閉鎖手術 を施行する予定である。

\section{文献}

1）狩野 敦, 斎藤 裕, 井上義博, 他: 腐蝕性食 道炎・胃炎. 総合臨床 $38: 521 \sim 525,1989$.

2）椎名泰文, 野見山哲, 三浦敏洋, 他: 経過を観 察しえた腐蝕性食道炎の 1 例. Progress of Digestive Endoscopy 23 : 147 150, 1983.

3) Yu Men Chen, David J OTT, James NT, et al : Progressive roentogenographic appearance of caustic esophagitis. South Med J 81 : 724 728, 1988.

4) Joyce AS : Caustic ingestion in adult patients. Laryngoscope $95:$ 1199 1201, 1985.

5）東口高志, 中井昌弘, 岡田喜克, 他 : 酸および 
アルカリによる腐蝕性食道炎 2 例の治療経験。 日消外誌 $17: 85 \sim 90,1984$.

6）門馬久美子, 吉田 操, 井出博子 : 腐蝕性食道 炎拉よび食道拡張術後. JOHNS $5: 207 \sim 210$, 1989.

7) Ronald $\mathrm{CH}$ and John $\mathrm{C}$ : Surgical treatment of hypopharyngeal stenosis in children. Laryngoscope 89 : 1593 1599, 1979.

8）中村隆美, 加藤公敏, 星野尚久, 他 : 苛性ソダ誤领による腐蝕性食道炎の 1 例. 消火器内視 鏡の進歩 33：162〜164, 1988.

9) Donald BH, Milan JD and Thomas E : Caustic ingestion; controversies in management. A review of 214 cases. Laryngoscope $90: 98 \sim$ 109, 1980.
10) Symbas PN, Vlasis $S E$ and Hatcher CR Jr : Esophagitis secondary to ingestion of caustic materials. Ann Thorac Surg 36 : 73 77, 1983.

11）八坂 朗, 嶺 博之, 雷 哲郎, 他: 本邦にお ける良性食道疾患に併存した食道癌. 日消外誌 $17: 681 \sim 689,1984$.

12) Sabial G : Total obliteration of esophagus and hypopharynx due to corrosives ; a new technique of reconstruction. J Thorac Cardiovasc Surg $60: 264 \sim 268,1970$.

$$
\left(\begin{array}{l}
\text { 別冊請求先 : 越智健太郎 } \\
\text { T216 川崎市宮前区菅生 } 2-16-1 \\
\text { 聖マリアンナ医科大学耳鼻咽啹科学教室 }
\end{array}\right)
$$

